\title{
DIFFERENTIAL DIAGNOSTICS OF ASEPTIC AND SEPTIC LOOSENING OF THE CUP OF THE ENDOPROSTHESIS OF THE ARTIFICIAL HIP JOINT BY THE METHODS OF POLARISATION TOMOGRAPHY
}

\author{
Alexander G. Ushenko, Olexander Olar \\ Chernivtsi National University, Department of Optics and Publishing, Chernivtsi, Ukraine \\ Abstract. Manuscript contains structural-logical scheme and analytical description of the differential diagnosis of aseptic and septic loosening of the \\ artificial hip joint endoprosthesis using the methods of differential Mueller-matrix mapping of circular birefringence (CB) distributions of polycrystalline \\ synovial films $(S F)$ and results of determining the sensitivity, specificity and accuracy of the wavelet analysis method of differential Mueller-matrix \\ mapping of the distributions of the $C B$ values of polycrystalline films SF patients from the control group and groups with different severity of the hip joint \\ pathology.
}

Keywords: polarization tomography, Mueller matrix, circular birefringence, synovial films

\section{DIAGNOSTYKA RÓŻNICOWA ASEPTYCZNEGO I SEPTYCZNEGO OBLUZOWANIA PANEWKI ENDOPROTEZY STAWU BIODROWEGO METODAMI TOMOGRAFII POLARYZACYJNEJ}

Streszczenie. Manuskrypt zawiera schemat strukturalno-logiczny $i$ opis analityczny diagnostyki różnicowej aseptycznego i septycznego obluzowania sztucznej endoprotezy stawu biodrowego z wykorzystaniem metod różnicowego mapowania macierzy Muellera rozkładów dwójłomności kołowej polikrystalicznych filmów błony maziowej $i$ wyników określania czułości, swoistości i dokładności metody analizy falkowej różnicowego mapowania macierzy Muellera rozkładów wartości dwójłomności kołowej polikrystalicznych filmów SF pacjentów z grupy kontrolnej i grup o różnym nasileniu patologii stawu biodrowego.

Słowa kluczowe: tomografia polaryzacyjna, macierz Muellera, dwójłomność kołowa, błony maziowe

\section{Introduction}

Methods of laser polarimetry are among the most important in the development of the latest introscopy systems of the polycrystalline structure of biological layers. The main pivot of such techniques is the Muller-matrix polarimetry (MMP) $[9,11$, 15]. This optical technology provides the most complete information about the optical anisotropic properties of biological tissues.

This manuscript contains structural-logical schemes and analytical descriptions of the differential diagnosis of aseptic and septic loosening of the artificial hip joint endoprosthesis using the methods of differential Mueller-matrix mapping of circular birefringence $(\mathrm{CB})$ distributions of polycrystalline synovial films (SF) films and results of determining the sensitivity, specificity and accuracy of the wavelet analysis method of differential Mueller-matrix mapping of the distributions of the $\mathrm{CB}$ values of polycrystalline films SF patients from the control group and groups with different severity of the hip joint pathology [16, 17].

Table 1. structural-logical scheme of differential Mueller-matrix tomography of polycrystalline films of $S F$ in the differential diagnosis of aseptic and septic loosening of the endoprosthesis cup of an artificial hip joint

\begin{tabular}{|c|c|c|}
\hline \multicolumn{3}{|c|}{ Polycrystalline films of synovial fluid (SF) } \\
\hline \multicolumn{3}{|c|}{ Differential Mueller-matrix mapping of polycrystalline SF films } \\
\hline CB maps & & maps \\
\hline \multicolumn{3}{|c|}{ Statistical and correlation analysis } \\
\hline \multicolumn{3}{|c|}{$\begin{array}{l}\text { Mean values and fluctuations of the magnitude of the statistical moments of the } \\
1 \text { st - 4th orders characterizing the distribution of the value of CB of the samples } \\
\text { of samples of SF }\end{array}$} \\
\hline \multicolumn{3}{|c|}{$\begin{array}{c}\text { Information analysis of the Mueller-matrix polarization tomography method for } \\
\text { polycrystalline structure of SF films }\end{array}$} \\
\hline Sensitivity, $S e$ & Specificity, $S p$ & Accuracy, $A c$ \\
\hline \multicolumn{3}{|c|}{$\begin{array}{l}\text { Statistical analysis of the amplitude distributions of the wavelet coefficients of the } \\
\qquad \text { CB and LB cards }\end{array}$} \\
\hline \multicolumn{3}{|c|}{$\begin{array}{l}\text { Mean values and fluctuations of the magnitude of statistical moments of the 1st - } \\
\text { 4th orders, as well as the dispersion and sharpness of the peak of autocorrelation } \\
\text { functions within the set of CB maps of the polycrystalline structure of samples of } \\
\text { SF }\end{array}$} \\
\hline \multicolumn{3}{|c|}{$\begin{array}{c}\text { Information analysis of the Mueller-matrix polarization tomography method of } \\
\text { polycrystalline structure of SF films }\end{array}$} \\
\hline Sensitivity, $\mathrm{Se}$ & Specificity, $S p$ & Accuracy, $A c$ \\
\hline & & \\
\hline
\end{tabular}

\section{Differential diagnostics of aseptic and septic loosening of the endoprosthesis cup using the Mueller-matrix reconstruction}

This part of the research contains materials on the experimental implementation of polarisation reproduction with a comprehensive statistical and correlation analysis of the coordinate distributions of the magnitude of circular birefringence of polycrystalline films of synovial fluid of the hip joint of patients from the control group 1 and research groups 2 and 3 (section 3) [1, 16, 18].

An experimental method for determining the coordinate distributions of the magnitude of the $\mathrm{CB}$ of samples of SF polycrystalline films is presented in section 2 (clause 2, paragraph 2).

On a series of fragments of Fig. 1 presents the maps of the CB (left parts), the coordinate distributions of the magnitude of the $\mathrm{CB}$ (right parts) and the autocorrelation functions of the maps of the $\mathrm{CB}$ (lower parts), which are defined for the polycrystalline films of the SF of the hip joint of patients from group 1 (Fig. 1), group 2 (Fig. 2) and group 3 (Fig. 3) [2, 8, 20].

Comparison of the results of Mueller-matrix tomography (Fig. 2 - 4) of the parameters of the optical anisotropy of polycrystalline films of SF of the hip joint of patients of all groups revealed [14, 19, 23]:

- individual for each group of samples topographic structure of the coordinate distributions of the magnitude of CB (left parts of Fig. 1-3);

- significant range of coordinate-non-uniform change in the magnitude of circular birefringence (right parts of Fig. 1 - 3).

- complex and asymmetric structure for each of the groups of distributions of the eigenvalues of the autocorrelation functions (the lower parts of Fig. 1 - 3) [3, 10, 13]. 

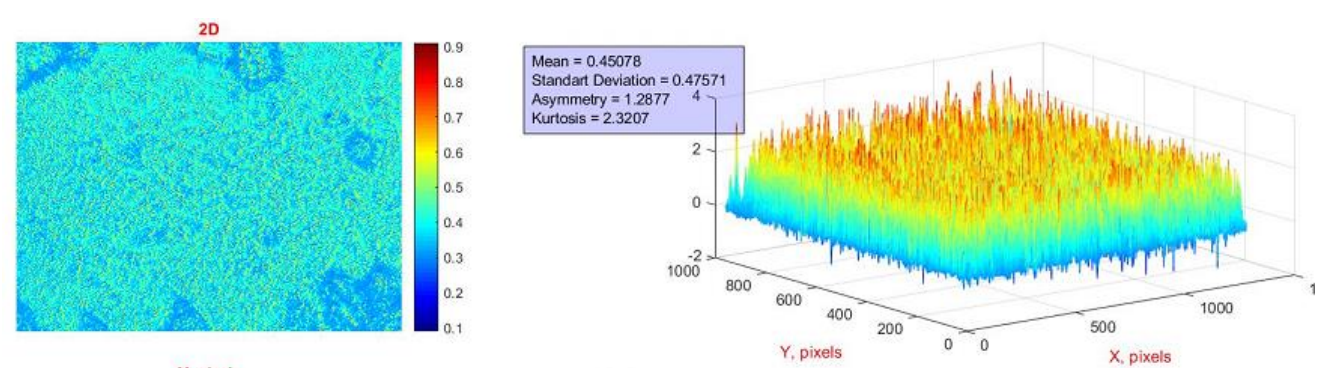

$\mathrm{X}$, pixels

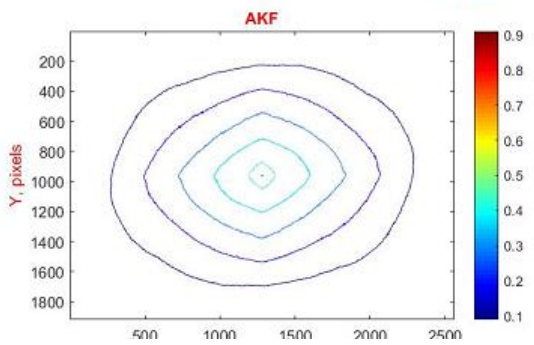

Fig. 1. Map (left side), coordinate distribution (right side) and autocorrelation function (lower part) of random variables of the CB of the SF polycrystalline film of a patient's syringe of group 1
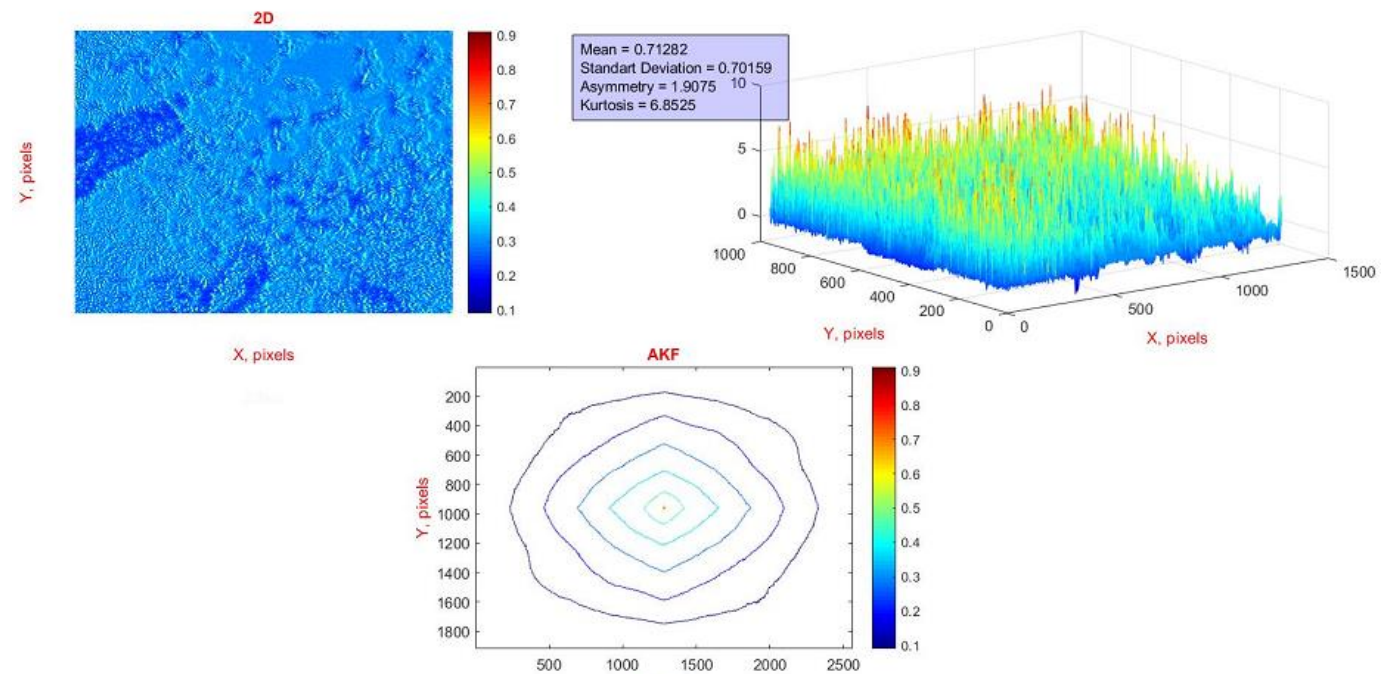

Fig. 2. Map (left side), coordinate distribution (right side) and autocorrelation function (lower part) of random variables of the CB of the SF polycrystalline film of a patient's syringe of group 2
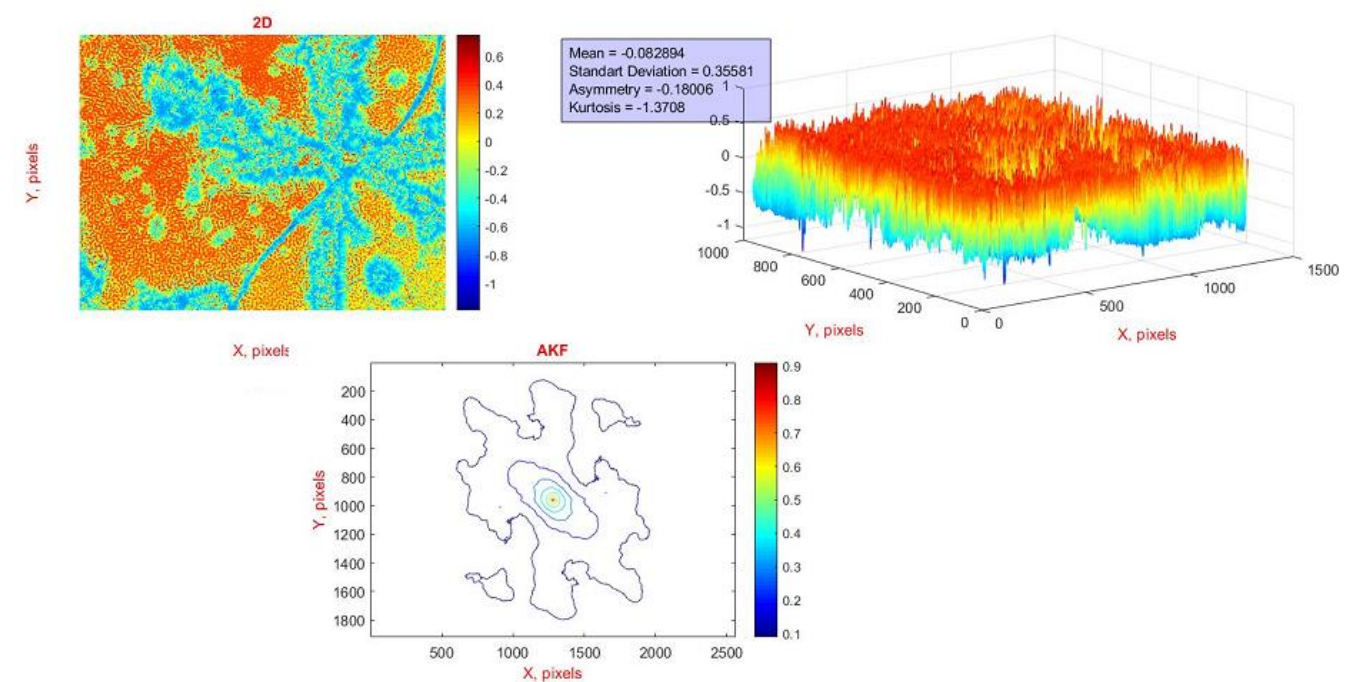

Fig. 3. Map (left side), coordinate distribution (right side) and autocorrelation function (lower part) of random variables of the CB of the SF polycrystalline film of a patient's syringe of group 3 


\subsection{Information analysis of the Mueller-matrix data reconstruction}

This section contains the results of determining the strength of the Mueller-Maric method of reproducing the distribution of the magnitude of the $\mathrm{CB}$ of SF polycrystalline films by calculating the magnitude of a set of operational characteristics - sensitivity, specificity and accuracy of the polarization tomography technique for all three groups of patients [12, 21, 22].

Table 2. Operational characteristics of the Mueller-matrix tomography method of circular birefringence of $S F$ polycrystalline films

\begin{tabular}{|c|c|c|c|c|c|}
\hline \multirow{2}{*}{$S T 1$} & \multicolumn{2}{|c|}{$S e$} & \multicolumn{2}{c|}{$S p$} & $A c$ \\
\cline { 2 - 6 } & 21 & 4 & 20 & 5 & 25 \\
\hline \multirow{2}{*}{$S T 2$} & 20 & $\mathbf{8 4}$ & \multicolumn{2}{|c|}{$\mathbf{8 0}$} & $\mathbf{8 2}$ \\
\cline { 2 - 6 } & \multicolumn{2}{|c|}{$\mathbf{8 0}$} & \multicolumn{2}{c|}{$\mathbf{8 0}$} & $\mathbf{8 0}$ \\
\hline \multirow{2}{*}{$S T 3$} & 22 & 3 & 22 & 3 & 25 \\
\cline { 2 - 6 } & \multicolumn{2}{|c|}{$\mathbf{8 8}$} & \multicolumn{2}{|c|}{$\mathbf{8 8}$} & $\mathbf{8 8}$ \\
\hline \multirow{2}{*}{$S T 4$} & 23 & 2 & 22 & 3 & 25 \\
\cline { 2 - 6 } & \multicolumn{2}{|c|}{$\mathbf{9 2}$} & \multicolumn{2}{|c|}{$\mathbf{8 8}$} & $\mathbf{9 0}$ \\
\hline \multirow{2}{*}{$S T 4$} & 21 & 4 & 20 & 5 & 25 \\
\cline { 2 - 6 } & \multicolumn{2}{|c|}{$\mathbf{8 4}$} & \multicolumn{2}{|c|}{$\mathbf{8 0}$} & $\mathbf{8 2}$ \\
\hline
\end{tabular}

These ST1 - ST4 - statistical moments 1-st - 4-th order, which characterise the distributions of the CB.
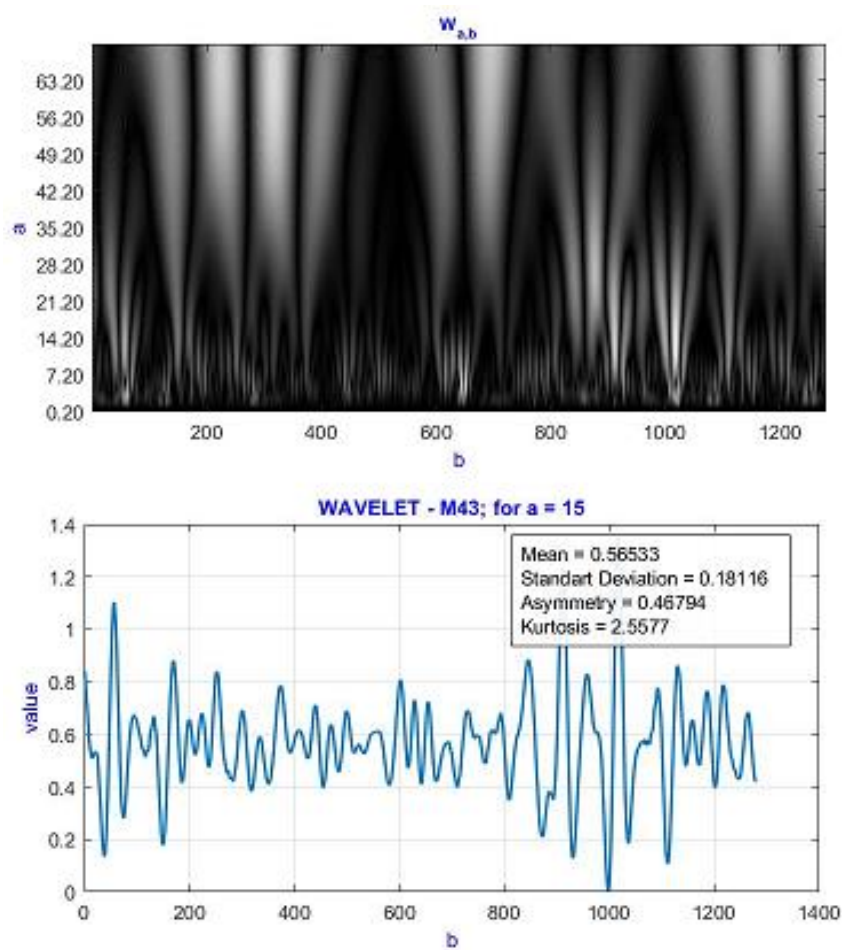

Fig. 4. The two-dimensional and linear distributions of the wavelet coefficients of the $C B$ map of the polycrystalline SF film of the knee joint of a patient from the control group 1
From the analysis of the operational characteristics of the method of polarisation reproduction of the distributions of the $\mathrm{CB}$ given in Table 2, the following follows:

- the range of variation of the specificity of the polarisation reproduction of the distributions of $\mathrm{CB}$ is $80 \% \leq S p \leq 88 \%$;

- the range of variation of the value of the balanced accuracy of the polarisation reproduction of the distributions of the $\mathrm{CB}$ is $82 \% \leq A c \leq 90 \%$

The overall level of the operational characteristics of the metrology of polarisation tomography (sensitivity, specificity and balanced accuracy) reaches $90 \%$.

The overall level of the operational characteristics of the polarisation tomography technique (sensitivity $S e$, specificity $S p$ and balanced accuracy $A c$ ) reaches $90 \%[4,7]$.

\subsection{Wavelet analysis of $\mathrm{CB}$ cards of polycrystalline SF films}

On fragments of the series Fig. $4-6$ shows the wavelet distribution coefficient map CB (upper part) linear section with the MHAT (Maxican hat) scale of function 15 (lower part). Quantitatively, changes in the distributions of the CB value, which is caused by the optical activity of polycrystalline SF films, which illustrate the distributions (mean and variance) of the amplitudes of the wavelet coefficients of maps of circular birefringence of SF samples of the hip joint of patients of all groups, which are presented in table $2[5,6]$.
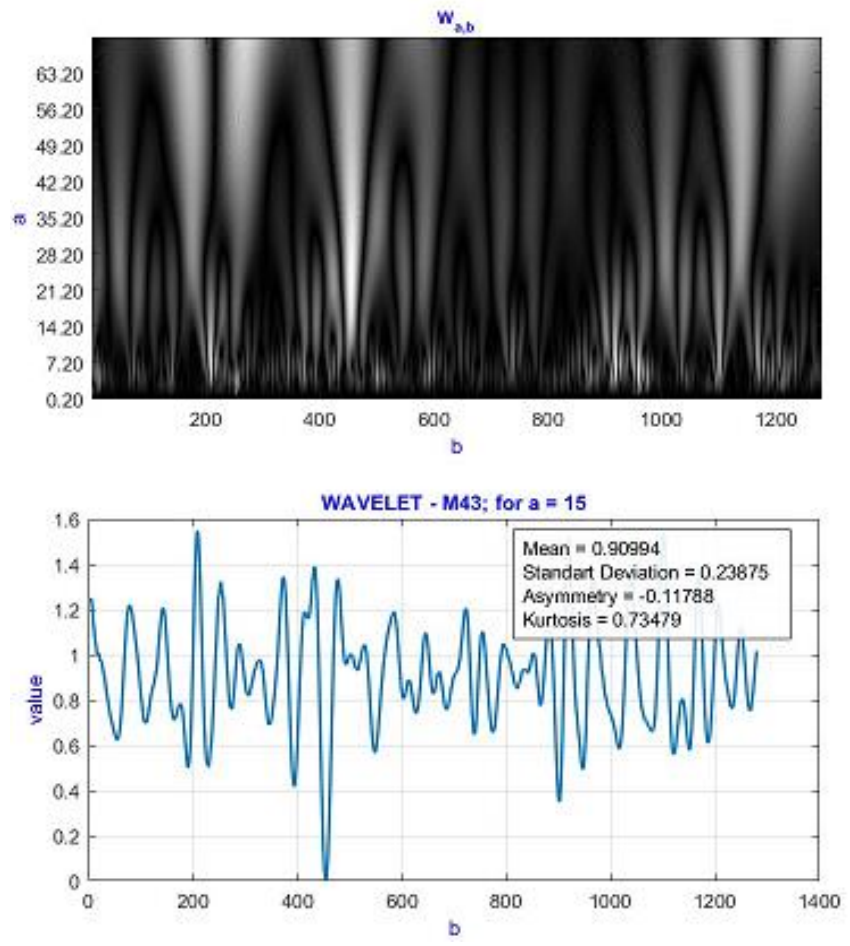

Fig. 5. The two-dimensional and linear distributions of the wavelet coefficients of the CB map of the polycrystalline film SF of the hip joint of a patient from group 1 

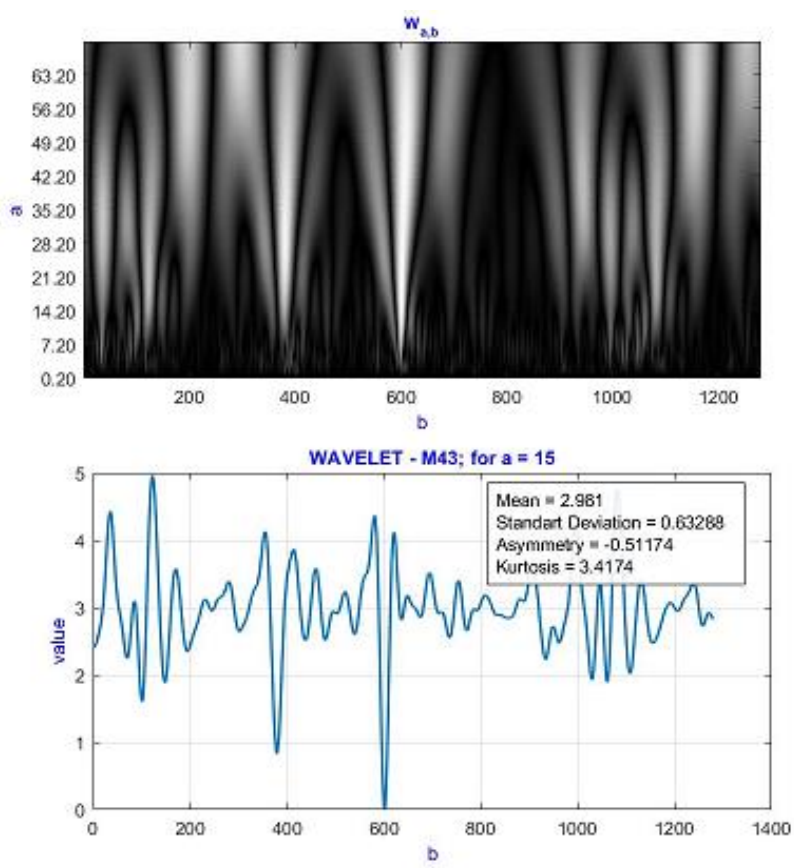

Fig. 6. The two-dimensional and linear distributions of the wavelet coefficients of the CB map of the polycrystalline film SF of the hip joint of a patient from group 3

\subsection{Information method of wavelet analysis of the distribution of $\mathrm{CB}$ values}

The data of the information analysis of the strength of the wavelet analysis method of the Muller-matrix tomography of the distribution of values of $\mathrm{CB}$ are presented in table 3 .

Table 3. Operational characteristics of the wavelet analysis method Muller-matrix reproduction distributions of the magnitude of CB polycrystalline films $S F$

\begin{tabular}{|c|c|c|c|c|c|}
\hline & \multicolumn{2}{|c|}{$\mathrm{Se}$} & \multicolumn{2}{|c|}{$S p$} & $A c$ \\
\hline \multicolumn{6}{|c|}{ Scale MHAT 55} \\
\hline \multirow{2}{*}{$S T 1$} & 21 & 4 & 21 & 4 & 25 \\
\hline & \multicolumn{2}{|c|}{84} & \multicolumn{2}{|c|}{84} & 84 \\
\hline \multirow{2}{*}{$S T 2$} & 22 & 3 & 21 & 4 & 25 \\
\hline & \multicolumn{2}{|c|}{88} & \multicolumn{2}{|c|}{84} & 86 \\
\hline \multicolumn{6}{|c|}{ Scale MHAT 15} \\
\hline \multirow{2}{*}{$S T 1$} & 23 & 2 & 22 & 3 & 25 \\
\hline & \multicolumn{2}{|c|}{92} & \multicolumn{2}{|c|}{88} & 90 \\
\hline$n$ & $a$ & $b$ & $c$ & $d$ & $n$ \\
\hline \multirow{2}{*}{$S T 2$} & 22 & 3 & 22 & 3 & 25 \\
\hline & \multicolumn{2}{|c|}{88} & \multicolumn{2}{|c|}{88} & 88 \\
\hline
\end{tabular}

\section{Conclusions}

It can thus be inferred that:

- the range of variation of the sensitivity value of the Muller matrix playback of $\mathrm{CB}$ cards is $84 \% \leq S e \leq 92 \%$;

- the range of variation of the magnitude of specificity of the Muller matrix playback of CB cards is $84 \% \leq S p \leq 88 \%$;

- the range of variation of the value of balanced accuracy. The Muller matrix playback of CB maps is $84 \% \leq A c \leq 88 \%$.

\section{Prof. Alexander G. Ushenko}

e-mail: o.ushenko@chnu.edu.ua

Prof., D.Sc., Yuriy Fedkovych Chernivtsi National University, Optics and Publishing Department, Chernivtsi, Ukraine.

Scientific interests: laser polarimetry of phaseinhomogeneous objects and media; development of methods of laser polarimetric diagnostics of pathological changes in tissues of the human body.

ORCID ID: 0000-0001-7015-7423
Thus, there is an increase in the overall level of the operational characteristics of the polarisation tomography technique (sensitivity $S e$, specificity $S p$ and balanced accuracy $A c$ ) of the distributions of circular birefringence of polycrystalline SF films to $87 \%-92 \%$.

\section{References}

[1] Dubolazov A.V., Marchuk V., Olar O.I., Bachinskiy V.T., Vanchuliak O.Ya., Pashkovska N.V., Andriychuk D., Kostiuk S.V.: Multiparameter correlation microscopy of biological fluids polycrystalline networks. Proc. SPIE 9066/2013, 90661Y.

[2] Koprowski R., Korzynska A., Wrobel Z., et al.: Influence of the measurement method of features in ultrasound images of the thyroid in the diagnosis of Hashimoto's disease. Biomedical Engineering Online 11/2012, 91.

[3] Kotyra A., Wójcik W., Gromaszek K., et al.: Assessment of biomass-coal cocombustion on the basis of flame image. Przegląd Elektrotechniczny 88(11B)/2012, 295-297.

[4] Kvyetnyy R., Bunyak Y., Sofina O., et al.: Blur recognition using second fundamental form of image surface. Proc. SPIE 9816/2015, 98161A.

[5] Kvyetnyy R., Romanyuk O., Titarchuk E., et al.: Usage of the hybrid encryption in a cloud instant messages exchange system. Proc. SPIE 10031/2016, 100314S.

[6] Kvyetnyy R., Sofina O., Orlyk P., Utreras A.J., Wójcik W., et al.: Improving the quality perception of digital images using modified method of the eye aberration correction. Proc. SPIE 10031/2016, 1003113.

[7] Kvyetnyy R.N., Sofina O.Yu., Lozun A.V., et al.: Modification of fractal coding algorithm by a combination of modern technologies and parallel computations. Proc. SPIE 9816/2015, 98161R.

[8] Lach Z., Smolarz A., Wójcik W., et al.: Optically powered system for automatic protection of a fiber segment. Przegląd Elektrotechniczny 84(3)/2008, 259-262.

[9] Lu S.: Interpretation of Mueller matrices based on polar decomposition. J. Opt. Soc. Am. A. 13/1996, 1106-1113.

[10] Maciejewski M., Surtel W., Wójcik W., et al.: Telemedical systems for home monitoring of patients with chronic conditions in rural environment. Annals of Agricultural And Environmental Medicine 21(1)/2014, 167-173.

[11] Nirmalya G.: Techniques for fast and sensitive measurements of twodimensional birefringence distributions. Journal of Biomedical Optics. 16(11)/2011, 110801

[12] Rovira R.H., Pavlov S.V., Kaminski O.S., Bayas M.M.: Methods of Processing Video Polarimetry Information Based on Least-Squares and Fourier Analysis. Middle-East Journal of Scientific Research 16(9)/2013, 1201-1204.

[13] Smolarz A., Gromaszek K., Wójcik W., et al.: Optical methods and artificial intelligence in diagnostics of industrial pulverized coal burner. Przegląd Elektrotechniczny 88(9B)/2012, 259-261.

[14] Timchenko L.I., Pavlov S.V., Kokryatskaya N.I., et al.: Bio-inspired approach to multistage image processing. Proc. SPIE 10445/2017, 104453M.

[15] Tower T.T.: Alignment Maps of Tissues: I. Microscopic Elliptical Polarimetry. Biophys. J. 81/2001, 2954-2963.

[16] Ushenko Yu.A., Dubolazov A.V., Balanetskaya V.O., Karachevtsev A.O., Ushenko V.A.: Wavelet-analysis of polarization maps of human blood plasma. Optics and Spectroscopy 13(3)/2012, 332-343.

[17] Ushenko Yu.A., Ushenko V.A., Dubolazov A.V., et al.: Mueller-matrix diagnostics of optical properties of polycrystalline networks of human blood plasma. Optics and Spectroscopy 112(6)/2012, 884-892.

[18] Wojcik W., Bieganski T., Kotyra A., et al.: Application of algorithms of forecasting in the optical fibre coal dust burner monitoring system: Proc. SPIE 3189/1997, 100-109.

[19] Wojcik W., Cakala S., Kotyra A., et al.: Analysis of the operation of an electrooptical Pockels effect. Proc. SPIE 3189/1997, 110-121.

[20] Wójcik W., Kotyra A., Ławicki T.: A quality factor of combustion of pulverized coal based on image analysis using the curvelet transform. Przegląd Elektrotechniczny 88(10B)/2012, 82-84.

[21] Zabolotna N.I., Pavlov S.V., Ushenko A.G., Karachevtsev A.O., Savich V.O., et al.: System of the phase tomography of optically anisotropic polycrystalline films of biological fluids. Proc. of SPIE 9166/2014, 916616.

[22] Zabolotna N.I., Pavlov S.V., Ushenko A.G., Sobko O.V., Savich V.O. Multivariate system of polarization tomography of biological crystals birefringence networks. Proc. of SPIE 9166/2014 916615.

[23] Zyska T., Wójcik W., Imanbek B., et al.: Diagnosis of the thermocouple in the process of gasification of biomass. Rocznik Ochrona Środowiska 18/2016, $652-666$

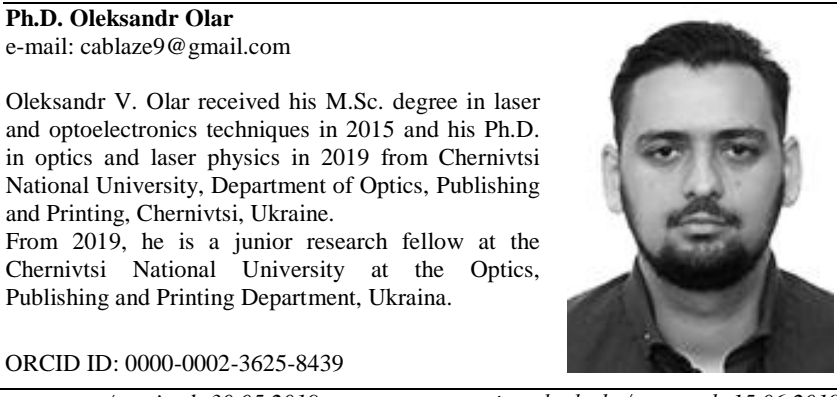

